\title{
FIELD SPARROW IN SASKATCHEWAN
}

\section{PAULE HJERTAAS, 919 Cook Crescent, Regina, Saskatchewan. S4X 2L9}

On 17 December 1982 Dale Hjertaas and I were fortunate enough to locate a Field Sparrow near Meyronne, Saskatchewan. We left Regina in the morning to participate in the Fort Walsh Christmas Bird Count. We stopped at Meyronne, on Highway 13 , southwest of Gravelbourg because Dale wanted to check the community pasture for Sage Grouse (he had seen them there in the past). Not seeing much sagebrush from the road, we decided to take the first turn west and proceed around the pasture to check the other sides. After a couple of miles, we reached a promising abandoned farmyard and decided to check it for Gray Partridges.

Dale was walking the outside perimeter and I was checking the inside hedgerows when a small bird hopped on a twig on the east side of the bushes in full sight. I could see a sparrow with a prominent white eye-ring and a very pink bill, legs and feet. My mind raced it could only be a Field Sparrow. "Dale, hurry, hurry, hurry! I see a Field Sparrow!" Well, I guess he could not hear well, being behind both me and the thick perimeter of trees; he came in only at half-speed, but with his toque halffalling off ... "I must have heard wrong" he said, "Did you say a Field Sparrow?" When he saw the bird, it wasn't anything he had seen before. He, also, first noticed the eye-ring and the color of the bill. Definitely a sparrow and one he did not know! "Keep an eye on it while I go get the field guide", he said.

The sparrow remained until Dale was over $50 \%$ convinced that it was a Field Sparrow and returned to the car to get the field notebook in which we recorded
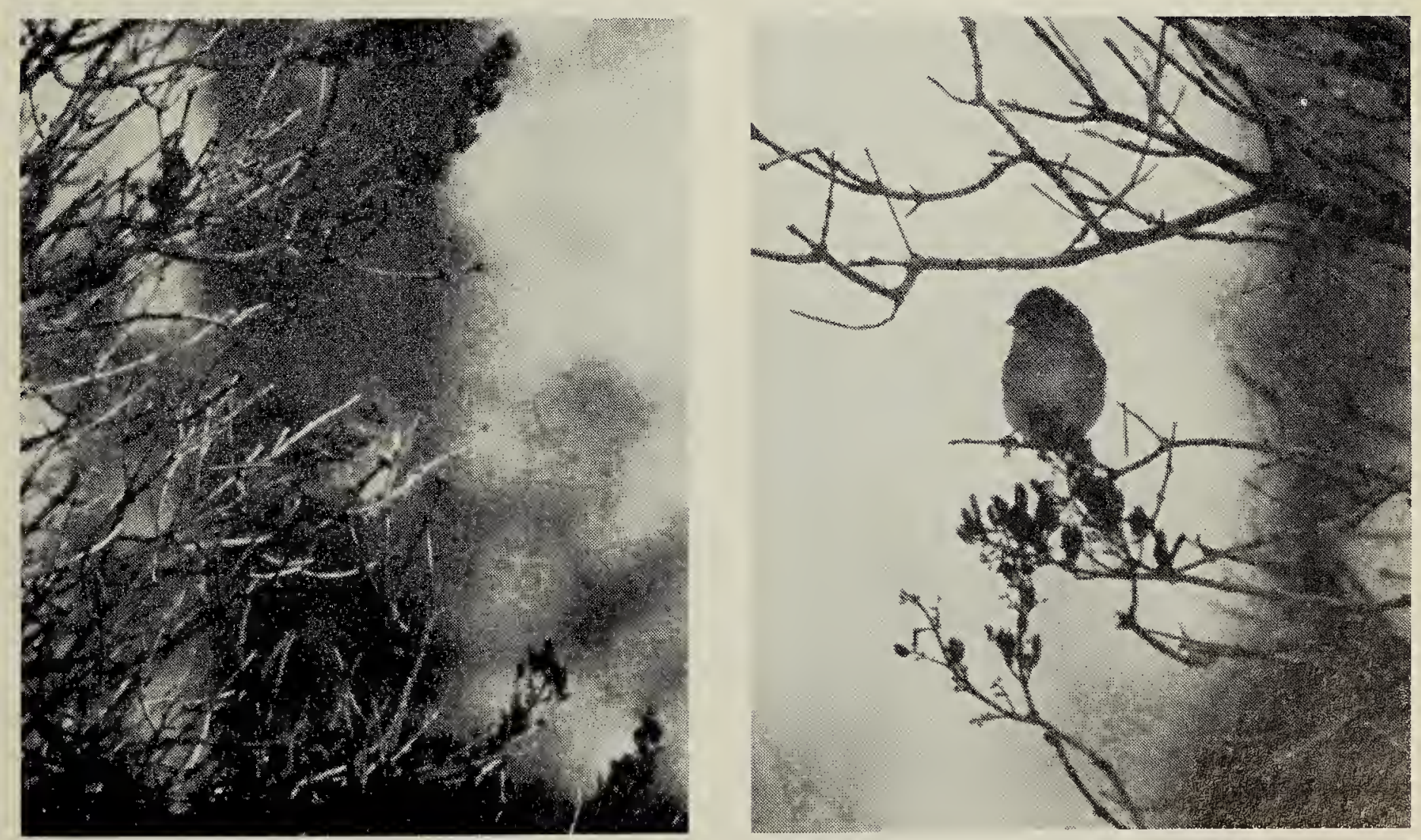

Chris Adam

John Triffo

Field Sparrow near Meyronne, Saskatchewan 
the following descrption:

"white eye-ring, pink bill, legs and feet, 2 buffy wing-bars, a buffy breast with no streaks or stick-pin, a striped back with quite a bit of brown in it, like a House Sparrow, a face pattern identical to the one illustrated in Peterson and Robbins for the Field Sparrow. The only difference with the illustrations is a pale rusty cap with a gray streak in the middle. The only way to see this last character is if the bird is looking you in the eyes... with both eyes..."

Peterson and Robbins do not give much detail on the plumage. ${ }^{3}$ Robbins et al state "Told by its pink bill and legs, unstreaked crown, and lack of a dark eye line" and Peterson "note the pink bill of this rusty capped sparrow ... a narrow eye-ring sometimes gives it a big-eyed expression." 53

In Robbins, the juvenile is represented as having a streaked breast and a full pale rusty cap, characters that are both different from what we observed, and Peterson does not illustrate the juvenile at all. ${ }^{5}{ }^{3}$ We were not absolutely discouraged though, as our experience with this genus of sparrow is that the young often have a streaked crown (e.g. Chipping and Swamp Sparrows).

We observed the bird for a half hour noting behavior. The call note in Peterson is described as "tsee," with a querulous quality but, to Dale and me, that sounds much like a lot of other sparrows. ${ }^{3}$ After I called a couple of times, our bird started giving a "tseep" call, more or less every 5 seconds, as it was moving through the bushes. Once in a while, it seemed to get excited and the call became a short "tsip," every second or so. It seemed to prefer the lilac clump as cover and returned there from other hedgerows and after foraging on the ground. In four foraging observations, it stayed on the ground between 10 and 60 seconds, then hurried deep into the lilac hedge. After 10 to 15 seconds, it would show up again at the edge of the branches.

Following the Fort Walsh and Govenloch CBC's, Bob Kreba, Chris Adam, Bill Russon and John Triffo (all from Regina) stopped at the farmyard on 19 December 1982, and found the bird in exactly the same clump of lilacs! They noticed all the characters I described previously, plus the pale rusty darker crescent around the shoulder. The light around 04:00 p.m. was still good enough for photography, and thus documentation of the Field Sparrow was obtained.

Only two of the reference books consulted gave data on the gray band across the crown. Bent, describes the eastern subspecies, Spizella pusilla pusilla with ". . . crown and nape rusty brown with a more or less evident median gray stripe ..." and Ridgway the western subspecies, S.p. arenacea with ". .. the pileum always (?) with a broad median stripe of gray, sometimes wholly gray, or with only a faint tinge of brown indicating the usual lateral stripes

"2 4 These references removed our lingering doubts about the crown stripe and indicated that the bird we saw was possibly of the western subspecies.

Perhaps the most surprising aspect of this observation is its timing. Field Sparrows breed as far north as southern Montana, North Dakota, Minnesota and southern Ontario and Quebec.2 ${ }^{46}$ Skaar considers the Field Sparrow as "probably breeding" within 70 miles of the International Border (49 ${ }^{\circ}$ latitude) immediately south of Meyronne. ${ }^{6} \mathrm{~A}$ breeding season bird would be only a 100-mile range extension, but the winter range is farther south. The closest observations to Saskatchewan in the 1972, '74, '78 and '80 Christmas Bird Counts published in American Birds were in southern Minnesota and Wisconsin, all south of $45^{\circ} \mathrm{N}$. latitude except one at a feeder in Ashland, 
Wisconsin, around $46^{\circ} 10^{\prime} \mathrm{N}$. The species is also present each year in some southern Ontario Counts. A breeding Field Sparrow could be expected in the south of Saskatchewan but this winter record is a considerable extension beyond the normal range.

I would like to thank Bob Kreba for providing a number of references and Dale Hjertaas for his decision to go on the Fort Walsh CBC, stopping at Meyronne on the way, thus enabling this discovery. Thanks also to Dale for reviewing this article.

ARBIB, R. S. Editor. American Birds. Christmas Bird Count Issues. April 1973, 27(2); April 1975, 29(2); July 1979, 33(4); July 1981, 35(4).
${ }^{2}$ BENT, A. C. 1978. Life Histories on North American Cardinals, Grosbeaks, Buntings, Towhees, Finches, Sparrows, and Allies, part 2. Dover Publications, Inc. New York, N.Y. 650 pages.

${ }^{3}$ PETERSON, R. T. 1969. A Field Guide to Western Birds. Second ed. Revised and enlarged. Houghton Mifflin Company. Boston, Mass. 366 pages.

${ }^{4}$ RIDGWAY, R. 1901. The Birds of North and Middle America, part 1. Bulletin of the United States National Museum No. 50. Government printing office, Washington.

${ }^{5}$ ROBBINS, C., et al. 1966. Birds of North America. Golden Press. New York, N.Y. 340 pages.

${ }^{6}$ SKAAR, P. D. 1980. Montana Bird Distribution. Second ed. P. D. Skaar, Bozeman, Montana.

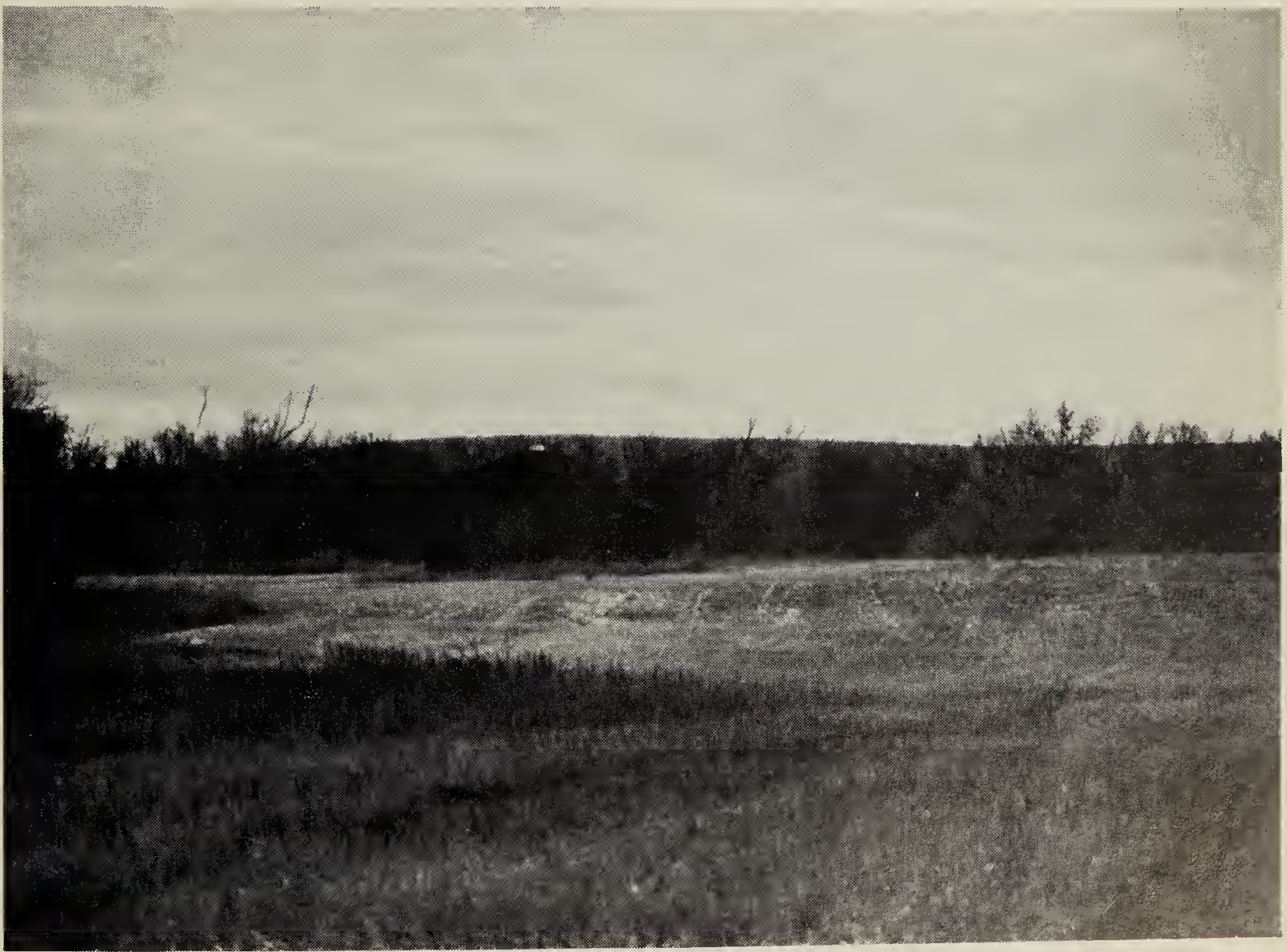

